Studies

Elsevier Editorial System(tm) for Design Manuscript Draft

Manuscript Number:

Title: Design Research - its 50-year transformation

Article Type: Full Length Article

Keywords: Design research, Design futures,

Corresponding Author: Professor Rachel Cooper,

Corresponding Author's Institution: Lancaster University

First Author: Rachel Cooper

Order of Authors: Rachel Cooper 


\section{Design Research - its 50-year transformation}

Rachel Cooper

Lancaster University

Email: R.cooper@Lancaster.ac.uk

Address: LICA Building, Lancaster University, Bailrigg, Lancaster LA1 4YW

Highlights:

Design research moves from process and methods to systems and services Design research moves from disciplines to challenges

Design research can help us address complex global and local challenges 


\title{
Design Research - its 50-year transformation
}

\begin{abstract}
Over the past half century, how we conceive of design research has changed significantly, as indeed have the boundaries of influence of the design profession. This paper takes an entirely personal perspective of the author and will discuss the change in the nature of design research through the lens of a career in design education and, especially, in the author's endeavours to develop design research as a respected discipline working with and alongside, science, social sciences and the arts and humanities. It will look at the social, economic and political drivers that have influenced design research in the UK but also globally, and at where this has taken design, in terms of research both within and beyond the design profession.
\end{abstract}

Key words: Design research, Design futures,

I was lucky enough to start my career in design in the early 1970 s at a time when there had been a decade or more of discourse around design science (Buckminster Fuller 1964, Sydney Gregory 1966, Herbert Simon 1996) and design methods (J Christopher Jones1963/1980 Bruce Archer 1965, Horst Rittel 1973), the history and importance of which has been explained very fully by Nigel Cross(Cross1993a, 1993b, and 2018). This group of scholars fully interrogated the nature of design and the degree to which it was a science, a method, a process or a way of working that could be codified. In doing so, they highlighted the unique nature of design and provided the context for the further development of design research generally and more specifically for later work into the way in which designers think and practice (Bryan Lawson 1980, Nigel Cross ,2011). There has been a massive transformation of design research since these early days and I will discuss that change though a personal lens of a career in design and design education. I hasten to say, this is not a precise timeline of events and development of theories, rather a descriptions of the waves of change that have occurred over the past 40 year of a career in design research. It is also necessarily UK focussed, as it is where I have spent my career, nevertheless it is clear many of the trends in design research I recount have been repeated across the world.

At the same time as the development of design methods theories and the emergence of the Design Studies Journal, the 1960s and 70s were an age of activism. Many of us will remember or know of the movements associated with the Vietnam war or the nuclear bomb (Campaign for Nuclear Disarmament) or activism related to the environment (Friends of the Earth, Greenpeace), feminism and equality (Women's Liberation Movement, Civil Rights movement) and the early concerns around disability, aging and social inequity epitomised perhaps by the iconic project of the hospital bed (one of the first to undertake formal design in the hospital environment) funded by the Kings Fund (Lawrence 2001). This informed the foundations of what we might now call responsible design, and designers and design academics began to consider the wider implications of design. For instance, Buckminster Fuller in his 1963 proposal for a comprehensive anticipatory design science proposed, 
'dedicating at least its next ten years to making the total worlds resources serve 100 percent of humanity at higher standards of living than hitherto experienced by any men(page 7)'. However, for me and many of my contemporaries studying design in the early 1970s, the most influential book of the period was Victor Papanek's Design for the Real World (1971). Suddenly, designers saw that they could work towards the benefit of society and the environment but also that what they designed could be damaging to the planet - thus, design's social and moral responsibility was brought into play. Alongside this was Germaine Greer's greatly influential work, The Female Eunuch (1970) which encouraged women to look at the way in which they were treated both in the work place and the home, and E F Schumacher's Small is Beautiful (1973), which asked designers to consider the unsustainable approach to economies, the use of natural resources, the human impact of technology and the need to consider sustainable development. However, 'responsible design' really didn't inform design research to any great extent for a significant period. Applying design to commercial outcomes remained a dominant force in design education, especially through the late 1970 s, 80 s and 90 s, when market forces tended to dominate the political and economic environments.

In the UK, during that same period, higher education went through a radical change. In the 1960s design education was overseen by the National Council for Diplomas in Art and Design, seen as the degree equivalent for Art and Design, and by the 1970s many art schools were subsumed into Polytechnics and design courses were awarded Bachelor of Arts (BA) status. I embarked on a new BA Hons in Multidisciplinary Design at North Staffordshire Polytechnic in 1973, the first such course in the UK. This course was developed and led by some visionary design teachers Cal Swann (1969) Graham Stevens (Orna and Stevens1995), with the idea to unlock the strait-jacket of graphic design, product design and other design disciplines. Students were able to choose from a range of design subject areas and to combine them in solving design problems, a course that echoed some of the principles that underpinned the Bauhaus. For me, this course illustrated that design had no disciplinary boundaries and that it was a problem-solving discipline.

As I negotiated the world of work in the mid 70s, I recognised that technology was changing around me, and decided I needed to study more, taking the opportunity in 1978 to do this as a research assistant at Manchester Polytechnic, Institute of Advanced Studies, another cross disciplinary 'research' centre. At that time, it was relatively unclear what the role of a research assistant was, nor what they were to do. I had complete charge of my time and my focus, which eventually, led to me completing my $\mathrm{PhD}$ in new technology and typography in 1982 and publishing my first Design Studies paper (Davies-Cooper 1984). This experience led to me learning from other disciplines, such as psychology and the social sciences, how to undertake research and what the value of research was to the discipline - PhDs in design at that time were relatively unknown and unexplored.

Thus, during this first wave of change in the 1960s and 1970s, design education in the UK became a valid, accredited, degree level discipline and internationally, design education started to be underpinned by theories of its method and process, in a climate of activism that began to influence the role of design in society and the economy.

During the 1980s and 1990s the growth in UK design education was driven by the move to transform those teaching institutions formally known as polytechnics change their names to 
universities. This was effectively completed in 1992 when the 'binary system' was abolished, and, in effect, all degrees were deemed the equivalent. This had the effect of forcing design (that had traditionally been located in the polytechnics with professional education as its focus) into a research environment. At that same time, there was growth in places at all universities and, therefore, a growth in design places too.

Funding and further promotion of research, especially related to design's contribution to the UK economy was initially promoted by UK Prime Minister Margaret Thatcher. In 1982 a summit on product design and market success was held with Thatcher later saying that the aim was to tap in to the knowledge "of successful men and women who are committed to the idea that good design is the cornerstone of successful business". The summit highlighted three issues;

- It was felt that Design was not valued or given enough emphasis at all levels of education,

- The awareness of design needed to be increased at all levels of management

- Public and private sector purchasers could influence the awareness of design amongst their suppliers.

This resulted in the Design Management Initiative supported by the Department of Trade and Industry (DTI), The Design Council and the Council for National Academic Awards (CNAA) (Cooper1993) and also the Design Innovation Group undertaking research on the value of design to industry (Walsh, Roy, Bruce and Potter 1992). In parallel in the USA, Colin Clipson, Director of the Architecture and Planning Research Laboratory at the University of Michigan, led 'The Competitive Edge, The Role of Design in American Corporations', an influential worldwide project producing four reports: a business design index, a database of books, periodicals and other materials on the role of design in business. (Cooper, Junginger, Lockwood 2011). So the second phase of design research was addressing the value of design to industry and the economy, and growth of design management, that had begun in the 1960s (Farr 1966) as a valid field of enquiry.

Whilst research was focussing on the push to understand the value and use of design in industry, the UK science budget grew alongside the growth and reorganisation of government funding bodies (Science White Paper, 1993) which, in particular, resulted in the reformation of the Engineering and Physical Sciences Research Council (EPSRC) and the creation of the Arts and Humanities Research Board (AHRC/B) in 1998, after a long campaign for the arts to be funded for research on the same basis as other disciplines, this was followed by its establishment as one of the Research Councils in 2005. Both the EPSRC and $A H R B / C$ recognised design within their portfolio and, within the AHRC this created stimulus programmes such as funding the AHRC designing for $21^{\text {st }}$ century programme (Inns 2007) that provided a mere $£ 6.5$ research funds for 21 clusters of design researchers and 20 projects. This programme has provided the basis for later research funding, for instance, more recently the Design Fellowship programme, Design for Change (AHRC 2017).

The emphasis on research grew wider and deeper when the UK government introduced, in 1986, Research Assessment Exercises (and has repeated them around every 5 years ever since) in every UK university. These are designed to assess the research outputs and research environment quality of all disciplines in universities and allocating research funding according to the results. This further increased the pressure on design academics to 
undertake research and resulted in an ongoing debate around the nature of design practice as design research, clearly illustrated by Frayling's (1993) seminal paper where he discussed research into art and design, research through art and design and research for art and design; topics that have been hotly debated ever since.

It was at this point I and colleagues around the world recognised the need to help nascent design researchers and to support the development of PhDs in design. This was not only a growth phenomenon in the UK but also internationally, especially in Europe. Where hitherto there were few journals in design that embraced the breadth of design research emerging (beyond the process, methods focus), we therefore saw the emergence of The Design Journal, and the new conferences such as the European Academy of Design, alongside the Design Research Society, which re-established its conferences (after nearly twenty years of absence).

This second wave of change, especially in the UK, began in the 1980s and 1990s where we saw both a growth in education generally, and a new emphasis on design education and an emerging funding stream for design research. Developing alongside this, we saw a growth in conferences and journals, which spread internationally across Europe, the USA, the middle east and, especially, South East Asia. We also saw economic forces driving the collaboration between design and other disciplines, principally, management disciplines.

As interest and funding in design research grew so did intellectual relationships between disciplines. I have already discussed the growth of Design Management in the drive to grow the economy through new product development in manufacturing. The relationship between marketing and design also attracted specific attention. Much work was undertaken to illustrate the interdependency between design and the marketing functions, in an organisation, from defining and testing customer need and demand to understanding how to launch and develop a product or brand using all the skills of product, graphic, interior and other relevant design disciplines. In marketing the 'customer was king', understanding the user or customer was the central focus of an innovative organisation both in the public and private sectors. In parallel, user-centred design became a significant approach and subject to much research, Donald Norman's (1986 \& 1988) work was a critical influence on the design community. Design research took seriously the level of engagement necessary to understand people, with interest in the social sciences beyond management, engagement with disciplines such as psychology, ethnography, anthropology, which became dispersed amongst the growing body of design researchers and, indeed, education with the development of specific courses in design ethnography or anthropology.

Another relationship that began to thrive was design and innovation. In design, we have always linked design and innovation, especially as the design profession tried to establish designs value to the economy. We can see this in the early work of James Pilditch (1976) as a design consultant, Christopher Lorenz (1986), management editor of the Financial times, and Peter Gorb, ex -business man who published Design Management (Gorb 1990) drawing on a series of seminars at the London Business School. This was followed by design and management researchers illustrating the link between good design and competitiveness through case study evidence (Walsh et al 1992). It continues to be subject to research by both management and design scholars, who often claim design drives innovation (Verganti 2009). Whilst in the management field Chesbrough (2003) led the 
development of Open Innovation as a management theory, which has been picked up by (Cruikshank \& Atkinson 2014). Theories in 'Design thinking' have also come from management scholars like Martin (2009) and design gurus such as Brown (2009) followed by the more considered thinking of design scholars such as Cross (2011). These developments have tended to consolidate the general assumption of the relationship between design, innovation and indeed creativity. Our tools for engagement now not only included design methods and process but also 'open innovation', 'open design' and 'design thinking', used as a means of working together with other people, such as customers, stakeholders, professions and users to adopt design methods and follow design processes to deliver design solutions and often, also to undertake design research.

\begin{abstract}
A third wave of change therefore was the development of practice and theory for use in applying design to innovation and productivity, pre-dominantly industry and economic challenges.
\end{abstract}

As the tools for the application of design developed so did the design lens. New topics upon which to apply design research and indeed design activity emerged and the whole field has mushroomed and new sub-disciplines developed. Take for instance Service Design, as we experienced growth of a service-based economy, particularly in the economies of the West, the marketing sub-discipline 'services marketing' emerged. This was natural for design as a discipline with a focus on the user, on design value in the development of non-tangible assets such as brands and on the product system, to develop theory and practice around design for services. The maturity of Service Design took over ten years, beginning in early 1990s with authors such Morelli, Hollins and Hollins, Manzini, Erlhoff et.al, Pancenti (Meroni and Sangiorgi, 2011) and the community did not really form around it as a valid discipline until mid the 2000s when various conferences and networks coalesced around the subject.

Taking this further, building on the activism around social and environmental issues and the growth in interest in social innovation, design for social innovation and social responsibility in organisations gained ground, led by academics such as Ezio Manzini and the development of the Design for Social Innovation and Sustainability (DESIS) Network. Whilst researchers and, indeed, the commercial sector (Livework, for example, was one of the first service design consultancies in the UK beginning work in early 2000s,) addressed service design, it was recognised that the focus on service maps, blueprints and pathways to delivering a service that worked in the commercial arena, could be applied to the need to address change in all areas of the public sector, including health, education and transport.

Another theory began to move design beyond service design in to the public sector more firmly. Richard Thaler and Cass Sunstein (2008) wrote Nudge: Improving Decisions About Health, Wealth, and Happiness. In this book, based on psychology and behavioural economics, 'Nudging' involves structuring the choices that people make so as to lead them towards particular outcomes, and they use design as one of the ways that you can 'nudge' behaviour, for instance putting the stairs next to an entrance rather than a lift to encourage activity (Baldwin 2014). Interestingly, in the late 1990s the Design against Crime research instigated by the UK Home Office and the Design Council used behavioural theories in crime prevention though design (Davey and Wootton 2017). Psychology and design had already 
illustrated this by Norman and others, so it was not new in design fields, but coming from an

Throughout these waves of change, design researchers never abandoned the cause-based issues of the 1960s, indeed, there continued a growth in design research applied to issues such as sustainability, inclusivity, or old age, for example. There may have been less cash for such research, but design researchers saw the value and continued to develop the field. Furthermore, design research has, due to the challenges presented, recognised the need for inter-disciplinary collaboration. I will not delve into that murky field of defining cross, inter/ post disciplinarity discussion here, suffice to say it is recognised that complex, wicked problems require multiple lenses and collaboration to address and answer the big global questions. Today, Design research is working beyond its own disciplinary boundaries and is focussed on the application of design research to a diversity of problems. The drivers are often political as well as economic, so in the UK, the industrial strategy whilst focused on

Both design for services and design for policy development put a great deal of focus on cocreation, participatory design and co-design, both at organisational and individual levels. The confluence of the focus on the user, the organisation, competitiveness and innovation and the way in which design can result in change with both positive and negative outcomes, again reverberated across the design research domain (Cooper \& Boyko). This, of course, draws on processes of creative thinking, visualisation, collaboration, making and the design process itself. Buchannan's (2001) 'Four Orders of Design' has been widely cited by those wishing to understand and categorise what was happening, as an interpretation of the transformation of design, moving from designing messages and things to designing services and systems. This was also a period where we were consolidating the notion of the power of design to make 'meaning' rather than just form and function, as illustrated in Krippendoff's (2006) work on 'the semantic turn'. I would argue that we, in both cases, are still using the craft of the design process (Hernandez, Cooper,Tether, Murphy 2018). However, I believed we clearly needed to illustrate the role of design in the literature quite differently, and to undertake research more systematically to illustrate this. Therefore, in 2004, I initiated and edit a book series on design for social responsibility, focused on how design contributes to Health, Crime, Services, Sport, Transport, Policy, Sustainability, Personalisation and Inclusivity.

So, the fourth wave saw a nexus of a number of theories, often popularised outside the design domain, coming together to influence the direction of design research; i) understanding the people ii) moving away from the design of the tangible to the design of the intangible iii) the growth of interest in creative innovation and the way designers think to increase competitiveness and innovation, thus driving forward the economy, and improving services in the public and private sector. Finally, and, critically, we saw the adoption of design by researchers outside the discipline. 
productivity, is also trying to address an ageing society, clean growth, the future of mobility and artificial intelligence and Data. Whilst global challenges revolve around the UN's 17 sustainable development goals related to poverty, inequality, climate, environmental degradation, prosperity, and peace and justice.

Design research applied to sustainability, health and other global challenges has indeed improved its ability to provide evidence, lobby industry, government and society, through both individual and group output and representative bodies and networks (e.g. DRS, Cumulus, ISDAR, EAD), the latter seeing a tremendous growth in number and membership in the past 50 years.

Bearing this in mind, there is still a threat on the horizon for design researchers. The promise of the user centred approaches, of co-design, participatory design etc. and indeed that of design thinking has meant that other academic disciplines have recognised both the value and, perhaps, the popular appeal and started to capitalise on this and draw them into their own research domains. Critics might argue that this has often been without detailed knowledge or insight into the attributes of such methods. It is now an imperative that academics in the design domain make sure that this does not result in a diminution of respect for design methods and research in the long term. We must also ensure that design researchers continue to influence political and global policy organisations.

We are now partway through the fifth wave where we are using design to understand the future. This is at a time when we see fragmentation and conflicts of world views and ideas, where the trends in technology, such as robotics, Al, Machine Learning and IOT in advanced economies are changing both economic and social values and structures, and where there is a growth in non-communicable i.e. lifestyle diseases, globally, and the health of the planet is in a critical trajectory. Now, more than ever, we need to try to understand the future, and design researchers can use methods drawn from the creative design process, to imagine futures, to build and to test them. We are now using these methods to address the complex wicked problems by using design fiction in world building and engaging conversations (Coulton and Lindley 2017). For instance, in the world of technology and IOT when things have intelligence and are connected together, we are considering a new way of approaching design beyond user centred design to object orientated design research.( Lindley et al 2017) We are using design fiction and design speculation to world build and test alternative futures whilst engaging with communities to understand their reactions. We are influencing policy by addressing upstream problems in public health such as encouraging mobility and activity by urban design and co-designing food systems (Cooper et al 2018).

The intention in the paper was to review the transformation of design research, with a critical eye, on how my own research career has changed over the period. In 2006, I was lucky enough to be funded to create a design research centre, ImaginationLancaster. Building on the trends I had recognised and described above, we were able to create a design agnostic research lab, aimed at conducting applied and theoretical research into people, products, places and their interactions, working with a variety of organisations to provide fresh perspectives on real-world issues and facilitate innovation. From the seven people who originally launched ImaginationLancaster in 2007, we have grown to an academic team of 5 Lecturers, 3 Senior Lecturers, and 6 Professors, with 11 support staff and, in 2019, we were funded again to double our size and to transform the UK research landscape by illustrating 
the capacity of design research methods to bind disciplines together, to deliver interdisciplinary research providing fresh perspectives on real world issues and so catalyse innovation, delivering new solutions to complex challenges (sustainability, health, prosperity) related to future cities, communities, factories and workplaces and homes. Looking at what design research brings to the world and where it is both unique and synergist with other disciplines, design is able to apply a long tail of knowledge to a distant horizon, whilst pulling together deep histories of knowledge in multiple domains to inform the future. This is a complex challenge for design research because we do not want to lose ourselves down a black hole of plurality, however, the challenge now is to ensure the next generation of design researchers are able to illustrate this capacity and have the credibility to have influence at the highest possible levels, in governments, in global agencies, in global companies, as well as at home in the small companies and communities.

The fifth wave offers the significant potential of design, to change the world at all levels and to do so in an ethical, trustworthy and collaborative manner.

Archer, L. B. (1965) Systematic Method for Designers, UK: The Design Council,

Baldwin, R. (2014) From regulation to behaviour change: giving nudge the third degree. The Modern Law Review, 77 (6).

Brown, T. (2009) Change by Design: how design thinking transforms organisations and inspires innovation, New York; Harper Collins.

Bruce, M., Cooper, R. (1997) Marketing and Design Management, London: Routledge,

Buchanan R (2001) Design Research and the New Learning, Design Issues 17, 4.

Buckminster Fuller, R. (1963) World Design Science Decade Phase 1 Document 1, Estate of Buckminster Fuller, Google Books

Davies-Cooper, R. (1984)

Cooper, R. (1993) Managing Design: Directions in British Education, Design Management Journal, 4, 3.

Cooper, R., Junginer, S., Lockwood, T. (2011) The Handbook of Design Management, London: Berg Publishers

Cooper, R., Boyko., C, (2011) Design for Health: the relationship between Design and Noncommunicable Diseases, Journal of Health Communication 16: pp134 -157

Cooper, R., Dunn, N., Coulton, P., Walker, S., Rodgers, P., Cruikshank, L., Tsekleves, E., Hands, D., Whitham, R., Boyko, C.T., Richards, D., Aryana, B., Pollastri, S., Escalante, M.A.L., Knowles, B., Lopez-Galviz, C., Cureton, P., Coulton, C. (2018) 
ImaginationLancaster: Open-ended, Anti-Disciplinary, Diverse, She Ji: The Journal of

Design, Economics, and Innovation. 4, 4, p. 307-341.

Chesbrough, H. (2003) Open Innovation: The New Imperative for Creating and Profiting from Technology. Boston: HBS Press.

Coulton, P., Lindley, J.G. (2017) Design fiction: anticipating adoption, IEEE Pervasive Computing. 16, 1, p. 43-47.

Cross, N. (2011) Design Thinking: Understanding How Designers Think and Work, Oxford and New York: Berg/Bloomsbury

Cross, N. (1993) "Science and Design Methodology: A Review." Research in Engineering Design 5: 63-69.

Cross, N. (2018) Developing design as a discipline, Journal of Engineering Design, 29:12,

Cross, N. (1993) "A History of Design Methodology", in de Vries, J., N. Cross and D. P. Grant (eds.), Design Methodology and Relationships with Science, The Netherlands: Kluwer Press. 15-27.

Cruickshank, L., Atkinson, P. (2014) Closing in on Open Design, The Design Journal, 17:3, 361-377,

Davey, C, L., Wootton A, B. (2017) Design Against Crime, a human centred approach to designing for safety and security, Abingdon: Gower.

Design for Change https://www.designresearchforchange.co.uk accessed 04.08.19

DESIS https://www.desisnetwork.org accessed 04.08.19

Farr, M. (1966) Design Management, London: Hodder \& Stoughton,

Frayling, C. (1993) Research in Art and Design, Royal College of Art Research Papers, Volume 1, Number 1, London

Fuller, R. Buckminster; McHale, J. (1964). "World Design Science Decade documents". Buckminster Fuller Institute. Southern Illinois University. Retrieved 04.08.19

Gorb, P. Design Management, Papers from London Business School, London: Architecture, Design and Technology Press

Greer, Germaine (1970). The Female Eunuch. London: MacGibbon \& Kee

Gregory, Sydney (1966). The Design Method. UK: Butterworth

Hernandez, R, J., Cooper, R., Tether, B., Murphy, E., (2018) Design, the Language of Innovation: A Review of the Design Studies Literature, She Ji: The Journal of Design, Economics, and Innovation 4,3, 249-274

Inns, T. (2007) Designing for the 21st Century: Interdisciplinary Questions and Insights. London: Gower 
Jones, J. C., Thornley D. G., (eds) (1963) Conference on Design Methods, UK: Pergamon Press,

Jones, J. C. (1980). Design Methods. Chichester: Wiley.

Krippendoff, K. (2006) The Semantic Turn, a new foundation for design, London: Taylor and Francis

Lawson, B. (1980) How Designers Think, London: Architectural Press,

Lawrence, G. (2001) Kings Fund Bed, The Lancet, September 8.

Lindley, J.G.,Coulton, P.,Cooper, R.(2017) Why the internet of things needs object orientated ontology, Proceedings of EAD 2017. $12 \mathrm{p}$.

Lorenz (1986) The Design Dimension, The Competitive Weapon for Business, Oxford: Basil Blackwell

Martin, R. (2009) The Design of Business; why design thinking is the next competitive weapon, Boston: Harvard Business Press.

Meroni, A., Sangiorgi D., (2011) Design for Services, London: Gower,

Norman, D. A., Draper S W (1986) User-Centered System Design: New Perspectives on Human-Computer Interaction, NJ, USA: L. Erlbaum Associates Inc. Hillsdale,

Norman, D.A., (1988) The Psychology of Everyday Things, New York, NY, US: Basic Books.

Orna, E., Stevens, G. (1995) Managing information for research, Milton Keynes: Open University Press,

Papanek, Victor. (1971). Design for the Real World: Human Ecology and Social Change, New York: Pantheon Books.

Pilditch, J. (1976) Talk about Design, London: Barrie \& Jenkins.

Rittel, W.J., Webber,M.M., (1973) Diliemmas in a General Theory of Planning, Policy Scinces 4, 155-169

Schumacher EF (1973) Small Is Beautiful: A Study of Economics As If People Mattered, Blond \& Briggs

Science White Paper (1993) May, Science and Environment Section, London: House of Commons Library

Simon, H. (1996). 'The Sciences of the Artificial. Cambridge, MA:

MIT Press.

Swann, C. (1969) Techniques of Typography, London: Lund Humphries

Thaler RH., Sunstein CR., (2008) Nudge: Improving Decisions about Health, Wealth, and Happiness, New Haven: Yale University Press 
Verganti, R. (2009) Design-Driven Innovation: changing the rules of competition by radically innovating what things mean, Boston: Harvard Business Press,

Walsh, V., Roy, R., Bruce, M., Potter, R. (1992) Winning by Design, Technology, Product Design and International Competiveness, Oxford: Blackwell Publishers, 


\section{Design Research - its 50-year transformation}

Rachel Cooper

Lancaster University

Email: R.cooper@Lancaster.ac.uk

Address: LICA Building, Lancaster University, Bailrigg, Lancaster LA1 4YW

\section{Highlights:}

Design research moves from process and methods to systems and services Design research moves from disciplines to challenges

Design research can help us address complex global and local challenges 


\title{
Design Research - its 50-year transformation
}

\begin{abstract}
Over the past half century, how we conceive of design research has changed significantly, as indeed have the boundaries of influence of the design profession. This paper takes an entirely personal perspective of the author and will discuss the change in the nature of design research through the lens of a career in design education and, especially, in the author's endeavours to develop design research as a respected discipline working with and alongside, science, social sciences and the arts and humanities. It will look at the social, economic and political drivers that have influenced design research in the UK but also globally, and at where this has taken design, in terms of research both within and beyond the design profession.
\end{abstract}

Key words: Design research, Design futures,

I was lucky enough to start my career in design in the early 1970 s at a time when there had been a decade or more of discourse around design science (Buckminster Fuller 1964, Sydney Gregory 1966, Herbert Simon 1996) and design methods (J Christopher Jones 1963/1980 Bruce Archer 1965, Horst Rittel 1973), the history and importance of which has been explained very fully by Nigel Cross(Cross1993a, 1993b, and 2018). This group of scholars fully interrogated the nature of design and the degree to which it was a science, a method, a process or a way of working that could be codified. In doing so, they highlighted the unique nature of design and provided the context for the further development of design research generally and more specifically for later work into the way in which designers think and practice (Bryan Lawson 1980, Nigel Cross ,2011). There has been a massive transformation of design research since these early days and I will discuss that change though a personal lens of a career in design and design education. I hasten to say, this is not a precise timeline of events and development of theories, rather a descriptions of the waves of change that have occurred over the past 40 year of a career in design research. It is also necessarily UK focussed, as it is where I have spent my career, nevertheless it is clear many of the trends in design research I recount have been repeated across the world.

At the same time as the development of design methods theories and the emergence of the Design Studies Journal, the 1960s and 70s were an age of activism. Many of us will remember or know of the movements associated with the Vietnam war or the nuclear bomb (Campaign for Nuclear Disarmament) or activism related to the environment (Friends of the Earth, Greenpeace), feminism and equality (Women's Liberation Movement, Civil Rights movement) and the early concerns around disability, aging and social inequity epitomised perhaps by the iconic project of the hospital bed (one of the first to undertake formal design in the hospital environment) funded by the Kings Fund (Lawrence 2001). This informed the foundations of what we might now call responsible design, and designers and design 
academics began to consider the wider implications of design. For instance, Buckminster Fuller in his 1963 proposal for a comprehensive anticipatory design science proposed, 'dedicating at least its next ten years to making the total worlds resources serve 100 percent of humanity at higher standards of living than hitherto experienced by any men(page 7)'. However, for me and many of my contemporaries studying design in the early 1970s, the most influential book of the period was Victor Papanek's Design for the Real World (1971). Suddenly, designers saw that they could work towards the benefit of society and the environment but also that what they designed could be damaging to the planet - thus, design's social and moral responsibility was brought into play. Alongside this was Germaine Greer's greatly influential work, The Female Eunuch (1970) which encouraged women to look at the way in which they were treated both in the work place and the home, and E F Schumacher's Small is Beautiful (1973), which asked designers to consider the unsustainable approach to economies, the use of natural resources, the human impact of technology and the need to consider sustainable development. However, 'responsible design' really didn't inform design research to any great extent for a significant period. Applying design to commercial outcomes remained a dominant force in design education, especially through the late 1970 s, 80 s and 90 s, when market forces tended to dominate the political and economic environments.

In the UK, during that same period, higher education went through a radical change. In the 1960s design education was overseen by the National Council for Diplomas in Art and Design, seen as the degree equivalent for Art and Design, and by the 1970s many art schools were subsumed into Polytechnics and design courses were awarded Bachelor of Arts (BA) status. I embarked on a new BA Hons in Multidisciplinary Design at North Staffordshire Polytechnic in 1973, the first such course in the UK. This course was developed and led by some visionary design teachers Cal Swann (1969) Graham Stevens (Orna and Stevens1995), with the idea to unlock the strait-jacket of graphic design, product design and other design disciplines. Students were able to choose from a range of design subject areas and to combine them in solving design problems, a course that echoed some of the principles that underpinned the Bauhaus. For me, this course illustrated that design had no disciplinary boundaries and that it was a problem-solving discipline.

As I negotiated the world of work in the mid 70s, I recognised that technology was changing around me, and decided I needed to study more, taking the opportunity in 1978 to do this as a research assistant at Manchester Polytechnic, Institute of Advanced Studies, another cross disciplinary 'research' centre. At that time, it was relatively unclear what the role of a research assistant was, nor what they were to do. I had complete charge of my time and my focus, which eventually, led to me completing my $\mathrm{PhD}$ in new technology and typography in 1982 and publishing my first Design Studies paper (Davies-Cooper 1984). This experience led to me learning from other disciplines, such as psychology and the social sciences, how to undertake research and what the value of research was to the discipline - PhDs in design at that time were relatively unknown and unexplored.

Thus, during this first wave of change in the 1960s and 1970s, design education in the UK became a valid, accredited, degree level discipline and internationally, design education started to be underpinned by theories of its method and process, in a climate of activism that began to influence the role of design in society and the economy. 
During the 1980s and 1990s the growth in UK design education was driven by the move to transform those teaching institutions formally known as polytechnics change their names to universities. This was effectively completed in 1992 when the 'binary system' was abolished, and, in effect, all degrees were deemed the equivalent. This had the effect of forcing design (that had traditionally been located in the polytechnics with professional education as its focus) into a research environment. At that same time, there was growth in places at all universities and, therefore, a growth in design places too.

Funding and further promotion of research, especially related to design's contribution to the UK economy was initially promoted by UK Prime Minister Margaret Thatcher. In 1982 a summit on product design and market success was held with Thatcher later saying that the aim was to tap in to the knowledge "of successful men and women who are committed to the idea that good design is the cornerstone of successful business". The summit highlighted three issues;

- It was felt that Design was not valued or given enough emphasis at all levels of education,

- The awareness of design needed to be increased at all levels of management

- Public and private sector purchasers could influence the awareness of design amongst their suppliers.

This resulted in the Design Management Initiative supported by the Department of Trade and Industry (DTI), The Design Council and the Council for National Academic Awards (CNAA) (Cooper1993) and also the Design Innovation Group undertaking research on the value of design to industry (Walsh, Roy, Bruce and Potter 1992). In parallel in the USA, Colin Clipson, Director of the Architecture and Planning Research Laboratory at the University of Michigan, led 'The Competitive Edge, The Role of Design in American Corporations', an influential worldwide project producing four reports: a business design index, a database of books, periodicals and other materials on the role of design in business. (Cooper, Junginger, Lockwood 2011). So the second phase of design research was addressing the value of design to industry and the economy, and growth of design management, that had begun in the 1960s (Farr 1966) as a valid field of enquiry.

Whilst research was focussing on the push to understand the value and use of design in industry, the UK science budget grew alongside the growth and reorganisation of government funding bodies (Science White Paper, 1993) which, in particular, resulted in the reformation of the Engineering and Physical Sciences Research Council (EPSRC) and the creation of the Arts and Humanities Research Board (AHRC/B) in 1998, after a long campaign for the arts to be funded for research on the same basis as other disciplines, this was followed by its establishment as one of the Research Councils in 2005. Both the EPSRC and $A H R B / C$ recognised design within their portfolio and, within the AHRC this created stimulus programmes such as funding the AHRC designing for $21^{\text {st }}$ century programme (Inns 2007) that provided a mere £6.5 research funds for 21 clusters of design researchers and 20 projects. This programme has provided the basis for later research funding, for instance, more recently the Design Fellowship programme, Design for Change (AHRC 2017).

The emphasis on research grew wider and deeper when the UK government introduced, in 1986, Research Assessment Exercises (and has repeated them around every 5 years ever since) in every UK university. These are designed to assess the research outputs and 
research environment quality of all disciplines in universities and allocating research funding according to the results. This further increased the pressure on design academics to undertake research and resulted in an ongoing debate around the nature of design practice as design research, clearly illustrated by Frayling's (1993) seminal paper where he discussed research into art and design, research through art and design and research for art and design; topics that have been hotly debated ever since.

It was at this point I and colleagues around the world recognised the need to help nascent design researchers and to support the development of PhDs in design. This was not only a growth phenomenon in the UK but also internationally, especially in Europe. Where hitherto there were few journals in design that embraced the breadth of design research emerging (beyond the process, methods focus), we therefore saw the emergence of The Design Journal, and the new conferences such as the European Academy of Design, alongside the Design Research Society, which re-established its conferences (after nearly twenty years of absence).

This second wave of change, especially in the UK, began in the 1980s and 1990s where we saw both a growth in education generally, and a new emphasis on design education and an emerging funding stream for design research. Developing alongside this, we saw a growth in conferences and journals, which spread internationally across Europe, the USA, the middle east and, especially, South East Asia. We also saw economic forces driving the collaboration between design and other disciplines, principally, management disciplines.

As interest and funding in design research grew so did intellectual relationships between disciplines. I have already discussed the growth of Design Management in the drive to grow the economy through new product development in manufacturing. The relationship between marketing and design also attracted specific attention. Much work was undertaken to illustrate the interdependency between design and the marketing functions, in an organisation, from defining and testing customer need and demand to understanding how to launch and develop a product or brand using all the skills of product, graphic, interior and other relevant design disciplines. In marketing the 'customer was king', understanding the user or customer was the central focus of an innovative organisation both in the public and private sectors. In parallel, user-centred design became a significant approach and subject to much research, Donald Norman's (1986 \& 1988) work was a critical influence on the design community. Design research took seriously the level of engagement necessary to understand people, with interest in the social sciences beyond management, engagement with disciplines such as psychology, ethnography, anthropology, which became dispersed amongst the growing body of design researchers and, indeed, education with the development of specific courses in design ethnography or anthropology.

Another relationship that began to thrive was design and innovation. In design, we have always linked design and innovation, especially as the design profession tried to establish designs value to the economy. We can see this in the early work of James Pilditch (1976) as a design consultant, Christopher Lorenz (1986), management editor of the Financial times, and Peter Gorb, ex -business man who published Design Management (Gorb 1990) drawing on a series of seminars at the London Business School. This was followed by design and management researchers illustrating the link between good design and competitiveness through case study evidence (Walsh et al 1992). It continues to be subject 
to research by both management and design scholars, who often claim design drives innovation (Verganti 2009). Whilst in the management field Chesbrough (2003) led the development of Open Innovation as a management theory, which has been picked up by design and non-design researchers and discussed in the context of Open Design (Cruikshank \& Atkinson 2014). Theories in 'Design thinking' have also come from management scholars like Martin (2009) and design gurus such as Brown (2009) followed by the more considered thinking of design scholars such as Cross (2011). These developments have tended to consolidate the general assumption of the relationship between design, innovation and indeed creativity. Our tools for engagement now not only included design methods and process but also 'open innovation', 'open design' and 'design thinking', used as a means of working together with other people, such as customers, stakeholders, professions and users to adopt design methods and follow design processes to deliver design solutions and often, also to undertake design research.

\section{A third wave of change therefore was the development of practice and theory for use in applying design to innovation and productivity, pre-dominantly industry and economic challenges.}

As the tools for the application of design developed so did the design lens. New topics upon which to apply design research and indeed design activity emerged and the whole field has mushroomed and new sub-disciplines developed. Take for instance Service Design, as we experienced growth of a service-based economy, particularly in the economies of the West, the marketing sub-discipline 'services marketing' emerged. This was natural for design as a discipline with a focus on the user, on design value in the development of non-tangible assets such as brands and on the product system, to develop theory and practice around design for services. The maturity of Service Design took over ten years, beginning in early 1990s with authors such Morelli, Hollins and Hollins, Manzini, Erlhoff et.al, Pancenti (Meroni and Sangiorgi, 2011) and the community did not really form around it as a valid discipline until mid the 2000s when various conferences and networks coalesced around the subject.

Taking this further, building on the activism around social and environmental issues and the growth in interest in social innovation, design for social innovation and social responsibility in organisations gained ground, led by academics such as Ezio Manzini and the development of the Design for Social Innovation and Sustainability (DESIS) Network. Whilst researchers and, indeed, the commercial sector (Livework, for example, was one of the first service design consultancies in the UK beginning work in early 2000s,) addressed service design, it was recognised that the focus on service maps, blueprints and pathways to delivering a service that worked in the commercial arena, could be applied to the need to address change in all areas of the public sector, including health, education and transport.

Another theory began to move design beyond service design in to the public sector more firmly. Richard Thaler and Cass Sunstein (2008) wrote Nudge: Improving Decisions About Health, Wealth, and Happiness. In this book, based on psychology and behavioural economics, 'Nudging' involves structuring the choices that people make so as to lead them towards particular outcomes, and they use design as one of the ways that you can 'nudge' behaviour, for instance putting the stairs next to an entrance rather than a lift to encourage activity (Baldwin 2014). Interestingly, in the late 1990s the Design against Crime research 
instigated by the UK Home Office and the Design Council used behavioural theories in crime prevention though design (Davey and Wootton 2017). Psychology and design had already illustrated this by Norman and others, so it was not new in design fields, but coming from an economist, suddenly, the nudge theory was seen as very persuasive by governments of the time, and in the UK, Prime Minister, David Cameron, set up the Behavioural Insights Unit in the Cabinet Office in 2010. This was followed four years later by the Policy Lab, and it was then clear how influential the design discipline had become with the appointment of $\mathrm{Dr}$ Andrea Siodmok as head of this unit inside government. Andrea is a trained designer, having been a lecturer in design and the Chief Designer at the Design Council, during her career. Design had reached policy makers, so we have design for policy!

Both design for services and design for policy development put a great deal of focus on cocreation, participatory design and co-design, both at organisational and individual levels. The confluence of the focus on the user, the organisation, competitiveness and innovation and the way in which design can result in change with both positive and negative outcomes, again reverberated across the design research domain (Cooper \& Boyko). This, of course, draws on processes of creative thinking, visualisation, collaboration, making and the design process itself. Buchannan's (2001) 'Four Orders of Design' has been widely cited by those wishing to understand and categorise what was happening, as an interpretation of the transformation of design, moving from designing messages and things to designing services and systems. This was also a period where we were consolidating the notion of the power of design to make 'meaning' rather than just form and function, as illustrated in Krippendoff's (2006) work on 'the semantic turn'. I would argue that we, in both cases, are still using the craft of the design process (Hernandez, Cooper,Tether, Murphy 2018). However, I believed we clearly needed to illustrate the role of design in the literature quite differently, and to undertake research more systematically to illustrate this. Therefore, in 2004, I initiated and edit a book series on design for social responsibility, focused on how design contributes to Health, Crime, Services, Sport, Transport, Policy, Sustainability, Personalisation and Inclusivity.

So, the fourth wave saw a nexus of a number of theories, often popularised outside the design domain, coming together to influence the direction of design research; i) understanding the people ii) moving away from the design of the tangible to the design of the intangible iii) the growth of interest in creative innovation and the way designers think to increase competitiveness and innovation, thus driving forward the economy, and improving services in the public and private sector. Finally, and, critically, we saw the adoption of design by researchers outside the discipline.

Throughout these waves of change, design researchers never abandoned the cause-based issues of the 1960s, indeed, there continued a growth in design research applied to issues such as sustainability, inclusivity, or old age, for example. There may have been less cash for such research, but design researchers saw the value and continued to develop the field. Furthermore, design research has, due to the challenges presented, recognised the need for inter-disciplinary collaboration. I will not delve into that murky field of defining cross, inter/ post disciplinarity discussion here, suffice to say it is recognised that complex, wicked problems require multiple lenses and collaboration to address and answer the big global questions. Today, Design research is working beyond its own disciplinary boundaries and is 
focussed on the application of design research to a diversity of problems. The drivers are often political as well as economic, so in the UK, the industrial strategy whilst focused on productivity, is also trying to address an ageing society, clean growth, the future of mobility and artificial intelligence and Data. Whilst global challenges revolve around the UN's 17 sustainable development goals related to poverty, inequality, climate, environmental degradation, prosperity, and peace and justice.

Design research applied to sustainability, health and other global challenges has indeed improved its ability to provide evidence, lobby industry, government and society, through both individual and group output and representative bodies and networks (e.g. DRS, Cumulus, ISDAR, EAD), the latter seeing a tremendous growth in number and membership in the past 50 years.

Bearing this in mind, there is still a threat on the horizon for design researchers. The promise of the user centred approaches, of co-design, participatory design etc. and indeed that of design thinking has meant that other academic disciplines have recognised both the value and, perhaps, the popular appeal and started to capitalise on this and draw them into their own research domains. Critics might argue that this has often been without detailed knowledge or insight into the attributes of such methods. It is now an imperative that academics in the design domain make sure that this does not result in a diminution of respect for design methods and research in the long term. We must also ensure that design researchers continue to influence political and global policy organisations.

We are now partway through the fifth wave where we are using design to understand the future. This is at a time when we see fragmentation and conflicts of world views and ideas, where the trends in technology, such as robotics, AI, Machine Learning and IOT in advanced economies are changing both economic and social values and structures, and where there is a growth in non-communicable i.e. lifestyle diseases, globally, and the health of the planet is in a critical trajectory. Now, more than ever, we need to try to understand the future, and design researchers can use methods drawn from the creative design process, to imagine futures, to build and to test them. We are now using these methods to address the complex wicked problems by using design fiction in world building and engaging conversations (Coulton and Lindley 2017). For instance, in the world of technology and IOT when things have intelligence and are connected together, we are considering a new way of approaching design beyond user centred design to object orientated design research.( Lindley et al 2017) We are using design fiction and design speculation to world build and test alternative futures whilst engaging with communities to understand their reactions. We are influencing policy by addressing upstream problems in public health such as encouraging mobility and activity by urban design and co-designing food systems (Cooper et al 2018).

The intention in the paper was to review the transformation of design research, with a critical eye, on how my own research career has changed over the period. In 2006, I was lucky enough to be funded to create a design research centre, ImaginationLancaster. Building on the trends I had recognised and described above, we were able to create a design agnostic research lab, aimed at conducting applied and theoretical research into people, products, places and their interactions, working with a variety of organisations to provide fresh perspectives on real-world issues and facilitate innovation. From the seven people who originally launched ImaginationLancaster in 2007, we have grown to an academic team of 5 
Lecturers, 3 Senior Lecturers, and 6 Professors, with 11 support staff and, in 2019, we were funded again to double our size and to transform the UK research landscape by illustrating the capacity of design research methods to bind disciplines together, to deliver interdisciplinary research providing fresh perspectives on real world issues and so catalyse innovation, delivering new solutions to complex challenges (sustainability, health, prosperity) related to future cities, communities, factories and workplaces and homes. Looking at what design research brings to the world and where it is both unique and synergist with other disciplines, design is able to apply a long tail of knowledge to a distant horizon, whilst pulling together deep histories of knowledge in multiple domains to inform the future. This is a complex challenge for design research because we do not want to lose ourselves down a black hole of plurality, however, the challenge now is to ensure the next generation of design researchers are able to illustrate this capacity and have the credibility to have influence at the highest possible levels, in governments, in global agencies, in global companies, as well as at home in the small companies and communities.

The fifth wave offers the significant potential of design, to change the world at all levels and to do so in an ethical, trustworthy and collaborative manner.

Archer, L. B. (1965) Systematic Method for Designers, UK: The Design Council,

Baldwin, R. (2014) From regulation to behaviour change: giving nudge the third degree. The Modern Law Review, 77 (6).

Brown, T. (2009) Change by Design: how design thinking transforms organisations and inspires innovation, New York; Harper Collins.

Bruce, M., Cooper, R. (1997) Marketing and Design Management, London: Routledge,

Buchanan R (2001) Design Research and the New Learning, Design Issues 17, 4.

Buckminster Fuller, R. (1963) World Design Science Decade Phase 1 Document 1, Estate of Buckminster Fuller, Google Books

Davies-Cooper, R. (1984)

Cooper, R. (1993) Managing Design: Directions in British Education, Design Management Journal, 4, 3.

Cooper, R., Junginer, S., Lockwood, T. (2011) The Handbook of Design Management, London: Berg Publishers

Cooper, R., Boyko., C, (2011) Design for Health: the relationship between Design and Noncommunicable Diseases, Journal of Health Communication 16: pp134 -157

Cooper, R., Dunn, N., Coulton, P., Walker, S., Rodgers, P., Cruikshank, L., Tsekleves, E., Hands, D., Whitham, R., Boyko, C.T., Richards, D., Aryana, B., Pollastri, S., Escalante, 
M.A.L., Knowles, B., Lopez-Galviz, C., Cureton, P., Coulton, C. (2018) ImaginationLancaster: Open-ended, Anti-Disciplinary, Diverse, She Ji: The Journal of Design, Economics, and Innovation. 4, 4, p. 307-341.

Chesbrough, H. (2003) Open Innovation: The New Imperative for Creating and Profiting from Technology. Boston: HBS Press.

Coulton, P., Lindley, J.G. (2017) Design fiction: anticipating adoption, IEEE Pervasive Computing. 16, 1, p. 43-47.

Cross, N. (2011) Design Thinking: Understanding How Designers Think and Work, Oxford and New York: Berg/Bloomsbury

Cross, N. (1993) "Science and Design Methodology: A Review." Research in Engineering Design 5: 63-69.

Cross, N. (2018) Developing design as a discipline, Journal of Engineering Design, 29:12,

Cross, N. (1993) "A History of Design Methodology", in de Vries, J., N. Cross and D. P. Grant (eds.), Design Methodology and Relationships with Science, The Netherlands: Kluwer Press. 15-27.

Cruickshank, L., Atkinson, P. (2014) Closing in on Open Design, The Design Journal, 17:3, 361-377,

Davey, C, L., Wootton A, B. (2017) Design Against Crime, a human centred approach to designing for safety and security, Abingdon: Gower.

Design for Change https://www.designresearchforchange.co.uk accessed 04.08.19

DESIS https://www.desisnetwork.org accessed 04.08.19

Farr, M. (1966) Design Management, London: Hodder \& Stoughton,

Frayling, C. (1993) Research in Art and Design, Royal College of Art Research Papers, Volume 1, Number 1, London

Fuller, R. Buckminster; McHale, J. (1964). "World Design Science Decade documents". Buckminster Fuller Institute. Southern Illinois University. Retrieved 04.08.19

Gorb, P. Design Management, Papers from London Business School, London: Architecture, Design and Technology Press

Greer, Germaine (1970). The Female Eunuch. London: MacGibbon \& Kee

Gregory, Sydney (1966). The Design Method. UK: Butterworth

Hernandez, R, J., Cooper, R., Tether, B., Murphy, E., (2018) Design, the Language of Innovation: A Review of the Design Studies Literature, She Ji: The Journal of Design, Economics, and Innovation 4,3, 249-274

Inns, T. (2007) Designing for the 21st Century: Interdisciplinary Questions and Insights. London: Gower 
Jones, J. C., Thornley D. G., (eds) (1963) Conference on Design Methods, UK: Pergamon Press,

Jones, J. C. (1980). Design Methods. Chichester: Wiley.

Krippendoff, K. (2006) The Semantic Turn, a new foundation for design, London: Taylor and Francis

Lawson, B. (1980) How Designers Think, London: Architectural Press,

Lawrence, G. (2001) Kings Fund Bed, The Lancet, September 8.

Lindley, J.G.,Coulton, P.,Cooper, R.(2017) Why the internet of things needs object orientated ontology, Proceedings of EAD 2017. 12 p.

Lorenz (1986) The Design Dimension, The Competitive Weapon for Business, Oxford: Basil Blackwell

Martin, R. (2009) The Design of Business; why design thinking is the next competitive weapon, Boston: Harvard Business Press.

Meroni, A., Sangiorgi D., (2011) Design for Services, London: Gower,

Norman, D. A., Draper S W (1986) User-Centered System Design: New Perspectives on Human-Computer Interaction, NJ, USA: L. Erlbaum Associates Inc. Hillsdale,

Norman, D.A., (1988) The Psychology of Everyday Things, New York, NY, US: Basic Books.

Orna, E., Stevens, G. (1995) Managing information for research, Milton Keynes: Open University Press,

Papanek, Victor. (1971). Design for the Real World: Human Ecology and Social Change, New York: Pantheon Books.

Pilditch, J. (1976) Talk about Design, London: Barrie \& Jenkins.

Rittel, W.J., Webber,M.M., (1973) Diliemmas in a General Theory of Planning, Policy Scinces 4, 155-169

Schumacher EF (1973) Small Is Beautiful: A Study of Economics As If People Mattered, Blond \& Briggs

Science White Paper (1993) May, Science and Environment Section, London: House of Commons Library

Simon, H. (1996). 'The Sciences of the Artificial. Cambridge, MA:

MIT Press.

Swann, C. (1969) Techniques of Typography, London: Lund Humphries

Thaler RH., Sunstein CR., (2008) Nudge: Improving Decisions about Health, Wealth, and Happiness, New Haven: Yale University Press 
Verganti, R. (2009) Design-Driven Innovation: changing the rules of competition by radically innovating what things mean, Boston: Harvard Business Press,

Walsh, V., Roy, R., Bruce, M., Potter, R. (1992) Winning by Design, Technology, Product Design and International Competiveness, Oxford: Blackwell Publishers, 


\section{${ }^{*}$ Conflict of Interest}

\section{Declaration of interests}

$\bigotimes$ The authors declare that they have no known competing financial interests or personal relationships that could have appeared to influence the work reported in this paper.

$\square$ The authors declare the following financial interests/personal relationships which may be considered as potential competing interests:

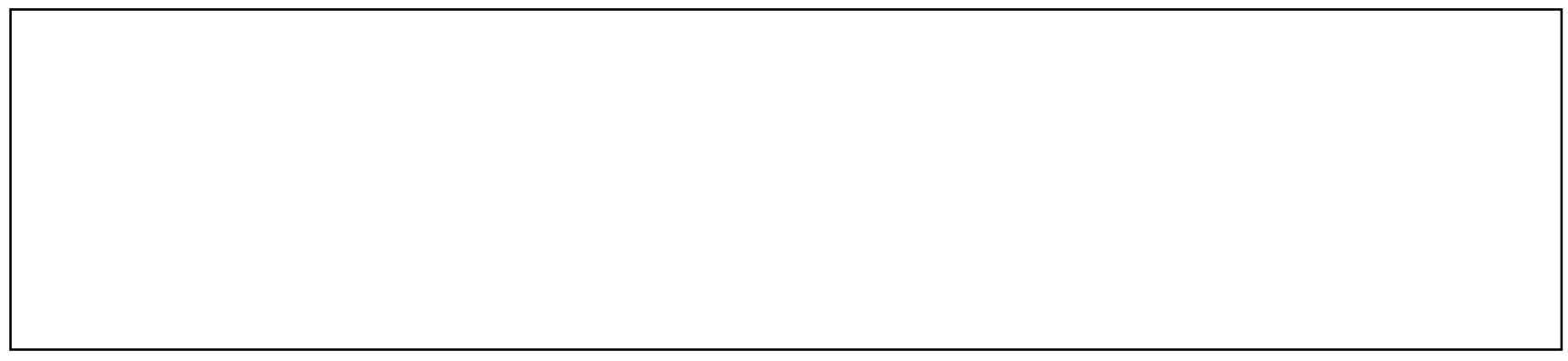

